\title{
The Southern Region of Kyrgyzstan: Modernity and Ethnic-Demographic Development
}

\author{
Gulnaz Chynykeeva', Abylabek Asankanov², Ainagul Zhooshbekova ${ }^{3}$, Amanzhol Kalysh', \\ Turdumamat Kadyrov', Aida Apyshova1, Gulzada Zhumashova1, Uulkan Tilekova5, \\ Zhypargul Abdullaeva ${ }^{*}$ (1)
}

${ }^{1}$ Department of World History and Teaching Methods of History, Faculty of Oriental Studies and History, Osh State University, Osh, Kyrgyzstan

${ }^{2}$ Institute of History, Archeology and Ethnology named after B. Zhamgerchinov, Bishkek, Kyrgyzstan

${ }^{3}$ Department of Kyrgyz history and Ethnology, I. Arabaev Kyrgyz State University, Bishkek, Kyrgyzstan

${ }^{4}$ Al-Farabi Kazakh National University, Almaty, Kazakhstan

${ }^{5}$ Department of Archeology and Ethnology, Osh State University, Osh, Kyrgyzstan

${ }^{6}$ Science and Research Department, Osh State University, Osh, Kyrgyzstan

Email: *jypar.science@oshsu.kg

How to cite this paper: Chynykeeva, G. Asankanov, A., Zhooshbekova, A., Kalysh, A., Kadyrov, T., Apyshova, A., Zhumashova, G., Tilekova, U., \& Abdullaeva, Z. (2020). The Southern Region of Kyrgyzstan: Modernity and Ethnic-Demographic Development. Open Journal of Social Sciences, 8, $1-12$.

https://doi.org/10.4236/jss.2020.810001

Received: August 18, 2020

Accepted: September 27, 2020

Published: September 30, 2020

Copyright ( 2020 by author(s) and Scientific Research Publishing Inc. This work is licensed under the Creative Commons Attribution International License (CC BY 4.0).

http://creativecommons.org/licenses/by/4.0/

\begin{abstract}
This article is investigating modernity and ethnic-demographic development in the southern region of Kyrgyzstan. Socio-economic and political reforms, market relations, social and economic instability in the country in early years of sovereignty decisively influenced by the dynamics and character of population. That is why a deep and comprehensive study of the Republics ethnic-demographic process is relevant nowadays. In this work, based on statistical data, the general description of population dynamics, its ethnic composition, and migration processes in a current ethnic-demographic situation was described.
\end{abstract}

\section{Keywords}

Ethnical, Demographic, Births, Deaths, Marriages, Divorces, Migration

\section{Introduction}

Ethno-demographic and ethnic processes are very complex and multifaceted phenomena (Rusi \& Cinnirella, 2012; Tzaneva, 2019). It includes a wide range of state, economic, legal, ideological, and psychological tasks (Williams, 1994). Therefore, scientists of various specialties such as philosophers, historians, ethnographers, linguists, psychologists, and sociologists pay special attention to the 
study of processes that lead to changes in one or another aspect of ethnic group life (Yang, 2017). Ethnic processes are developing under the influence of various factors, in particular of economic, regional, state, political, demographic, economic, cultural, linguistic, and psychological (Han \& Paik, 2017).

Growth rates, age distribution and size of population influencing shape the economy, environment, public pensions and health care (Lee, 2011). Ethnic arrangements can be influenced by geographical and ecological structures (Fei, 2017). A difference between terms such as "nation", "ethnic", and "ethnic group" is different in the social point of view, and political potential of ethnic communities (Gabbert, 2006).

Considering the fact, that at present the complex of tasks including ethnic aspects of population development remains open in ethnological science, we are describing demographic development of three areas in southern Kyrgyzstan. These regions are Batken, Jalal-Abad, and Osh oblasts, which are historical, and cultural centers occupying a special place in the development.

\section{Research Methods}

Some methods used in this study including a survey of respondents, analysis of statistical data, conversations with residents, representatives of local governments, observation during field research in the southern regions of Kyrgyzstan, analysis of media materials, and analysis of interviewed materials. The main source of research materials in this study based on the ethnic-sociological studies conducted in the southern regions of Kyrgyzstan. Ethno-sociological research was carried out in 2009 and is part of a large research project "Ethnodemographic and Migration Processes in the South of Kyrgyzstan" (supervised by the doctor of historical sciences, Professor A. Asankanov) conducted in Batken, Jalal-Abad and Osh regions. For the-sociological research, the cities and villages of southern Kyrgyzstan selected by the sampling method. All points of stationary research characterize all settlements of the studied area. Materials of ethnic-sociological research supplemented by field research data. When choosing, the main attention paid to the ethnic composition of the population. The questionnaire conducted in Kyrgyz. To give a complete picture of the demographic process of the population, statistical data, census materials, and many other materials used. Therefore, in January 1989, the territory of southern Kyrgyzstan at that time amounted to 77.8 thousand square meters. $\mathrm{km}$., it included 10 cities, of which eight oblasts, two district subordination. Besides, 14 urban-type settlements were registered. 165 village councils are working in 17 rural areas. $71 \%$ of the total population of southern Kyrgyzstan with a population of about 2 million people $(14,266,469)$ lived in rural areas, $29 \%(570,334)$ were urban residents (Sulaimanov, 1995).

Various questions concerning social problems such as: transition to market economics, employment, private business, wealth, migration, international relations were analyzed. 


\section{Results and Discussions}

During the formation of Kyrgyzstan as an independent sovereign state, according to resolution on December 14, 1990 No. 263 (Abdykalykov et al., 2010), “On improving the regional division of the Kyrgyz SSR and the formation of new regions" was adopted. On its basis, the Jalal-Abad region allocated from the Osh region. It included Ala-Bukinsky, Bazar-Korgonsky, Dzhany-Jolsky, Leninsky, Suzaksky, Toguz-Torousky, Toktogulsky, Chatkal districts, and cities of Jalal-Abad, Kara-Kol, Kok-Yangak, Mailuu-Suu, Tash-Kumyr. After that, an area of 32.4 thousand square kilometers allocated in the Jalal-Abad region (Bromley, 1987). In the sovereign Kyrgyz Republic, a resolution dated October 13, 1999 No. 110 "On the formation of the Batken region of the Kyrgyz Republic" from the Osh region and the transfer to it of the Kadamzhai, Leilek districts and the cities of Kyzyl-Kya, Sulukta within the existing administrative borders was adopted. The newly formed Batken oblast included Batken, Kadamzhay, Leilek districts, and the cities of Kyzyl-Kya, Sulukta with 17.0 thousand square $\mathrm{km}$. The administrative center of the region is the city of Batken (Sultanov et al., 2018).

In this section, questions concerning the employment by age, ethnic groups, interethnic relations, population migration including external migration and migration by sub-regions, and survey results obtained after social problems analysis described.

\subsection{Employment by Age}

The territory of Osh oblast is consisting of 7 administrative districts including Alai, Aravan, Kara-Kulzhinsky, Uzgen, Kara-Suuysky, Nookat, and Chon-Alai. Besides, the region includes 3 cities (Osh, Kara-Suu, Uzgen, and Nookat as a regional subordination), 2 urban settlements, 81 rural managements, and 467 uninhabited settlements. Scientists (Kozlov, 1969; Brook, 1986; Brooke \& Kabuzan, 1991; Bromley, 1987) and others emphasize that a scientific study of the ethnic-demographic situation prevailing in a particular region, republic, region and their analyses should meet the national strategic objectives of the area. Recent statistical surveys showed the following data shown in Table 1.

As can be seen from the above table, the total population of the Kyrgyz Republic by 2017 amounted to 6,140,200 people, including 2,959,770 people living in southern Kyrgyzstan, i.e. in three areas. Consequently, almost half of the total population and the majority of the working-age population live in these areas.

Table 1. The population of the south of Kyrgyzstan by age in 2017 (Sultanov et al., 2018).

\begin{tabular}{ccccc}
\hline Population & $\begin{array}{c}\text { Kyrgyz Republic } \\
\text { (people) }\end{array}$ & $\begin{array}{c}\text { Batken } \\
\text { (people) }\end{array}$ & $\begin{array}{c}\text { Zhalal-Abad } \\
\text { (people) }\end{array}$ & $\begin{array}{c}\text { Osh } \\
\text { (people) }\end{array}$ \\
\hline All population & $6,140,200$ & 503,514 & $1,168,731$ & $1,287,525$ \\
Yonger than employable & $2,063,913$ & 179,978 & 411,051 & 468,944 \\
Employable & $3,628,367$ & 292,827 & 687,713 & 742,707 \\
Older than employable & 447,920 & 30,709 & 69,967 & 75,874 \\
\hline
\end{tabular}




\subsection{Ethnic Groups}

It should be noted that ethnic processes could not be studied in isolation from the past and current history of one or another ethnic group, or without connecting with it. Therefore, more attention should be paid to an in-depth study of history, ethnography, culture, traditions, customs, etc. all living peoples, to focus all attention, not on circumstances leading to the separation of peoples. Table 2 is showing the ethnic population of the south Kyrgyzstan in 2017 (Sultanov et al., 2018). The ethnic lifestyle and historical conditions of peoples living in this territory are significantly different from other regions in Kyrgyzstan. To reveal these features, we have analyzed the processes of migration, ethnic composition, urbanization, rapprochement in the linguistic sphere of the population in this region.

According to Table 2, in 2017 the population of Kyrgyz Republic amounted to 6,140,200 people, where Uzbeks are 4,492,667 people. 73,650 Uzbek people were registered in Batken oblast, 296,064 in Jalal-Abad oblast, 370,519 in Osh oblast, 622,484 people with Uzbek nationality (the vast majority) live in southern Kyrgyzstan.

\subsection{Interethnic Relations}

In the course of this study, an attempt made to find out the opinion of people about future changes in interethnic relations. Interethnic relations improved, as $33.4 \%$ of men and women indicated that the relationship would remain the same. As can be seen from Figure 1, 62.3\% of the inhabitants of Batken, 58.3\% of the Jalal-Abad, and $48 \%$ of the Osh regions hope that international relations will improve. Residents of the Batken region are more optimistic about the future of interethnic relations than residents of other two regions. 35\% of respondents in Osh oblast believe that interethnic relations will remain the same. More people in this area feared deterioration in interethnic relations (16.2\%). As the June events showed, the residents of Osh and Jalal-Abad regions were not in vain afraid of the deterioration of interethnic relations in southern Kyrgyzstan.

Table 2. The ethnic population of the south Kyrgyzstan in 2017 (Sultanov et al., 2018).

\begin{tabular}{cccccccc}
\hline & $\begin{array}{c}\text { Kyrgyz } \\
\text { people }\end{array}$ & $\begin{array}{c}\text { Uzbek } \\
\text { people }\end{array}$ & $\begin{array}{c}\text { Russian } \\
\text { people }\end{array}$ & $\begin{array}{c}\text { Dungan } \\
\text { people }\end{array}$ & $\begin{array}{c}\text { Uyghur } \\
\text { people }\end{array}$ & $\begin{array}{c}\text { Tajik } \\
\text { people }\end{array}$ & Population \\
\hline Kyrgyz republic & $4,492,667$ & 898,363 & 356,637 & 69,093 & 56,015 & 53,848 & $6,140,200$ \\
Bishkek & 716,586 & 13,575 & 168,392 & 5022 & 15,435 & 999 & 980,369 \\
Zhalal-Abad & 840,538 & 296,064 & 6774 & 44 & 3806 & 6397 & $1,168,731$ \\
Naryn & 278,892 & 592 & 102 & 453 & 343 & 2 & 281,043 \\
Issuk-kul & 422,764 & 2900 & 28,610 & 3443 & 3970 & 52 & 476,760 \\
Osh & 873,551 & 122,552 & 4398 & 101 & 860 & 692 & 281,926 \\
Batken & 388,591 & 73,650 & 2509 & 3 & 339 & 34,537 & 503,514 \\
Talas & 238,156 & 1795 & 3386 & 80 & 142 & 40 & 255,150 \\
Chuy & 592,677 & 16,716 & 141,253 & 59,041 & 17,311 & 3353 & 905,182 \\
Osh region & 873,551 & 370,519 & 1213 & 906 & 13,809 & 7776 & $1,287,525$ \\
\hline
\end{tabular}




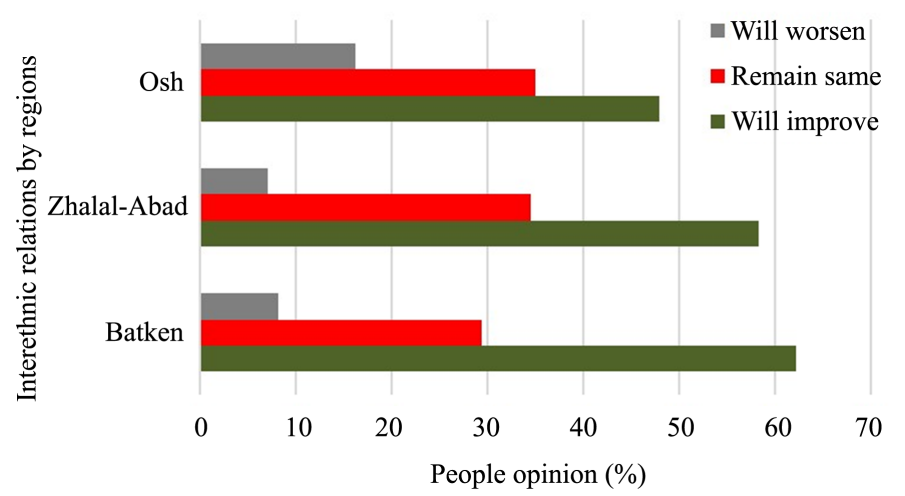

Figure 1. Changes in interethnic relations in the future, by regions, in\% (Chynykeeva, 2019).

\subsection{Population Migration}

One of the serious problems requiring attention in the socio-economic life of the region is the problem of migration. This important phenomenon has a direct impact on the socio-economic, demographic, ethnic processes in the region. In a word, population migration is a complex process. Features of its development directly determined by socio-economic and political conditions. Resettlement, moving from one place to another, large-scale population resettlement cannot but change to some extent the socio-ethnic structure of a village or city in a new host area. In Central Asia, the chain migration through networks of friends and relatives is common phenomena, where migrant workers usually connected with other migrants from their ethnic groups or hometowns (Ismayilova et al., 2014).

\subsubsection{External Migration}

Moreover, the increase of interethnic marriages affected changes in language, national psychology, culture, and life of the local population. Analysis of marriage histories from a nationally representative survey conducted in the period 2011-2012 to examine the dynamics of traditional marital practices between the country's two main ethnic groups, Kyrgyzs and Uzbeks, focusing on trends in arranged marriages (Nedoluzhko \& Agadjanian, 2015; Asankanov, 2009). Interethnic relations are becoming more relevant than before, and ethnic processes are becoming deeper, therefore, diverse studies are necessary, and have not only theoretical but also practical significance. Development of migration processes in recent years, trends have appeared that have a significant impact on the volume and structure of migration. Table 3 is showing the external migration of population by regions, in 2017 (Chynykeeva, 2019).

Table 3 is showing a comparison of population external migration by regions, and we see that migration activity is higher in comparison with other oblasts in Osh (-426) and Jalal-Abad (-320) regions. The proximity to the agricultural regions of the Fergana valley had a significant impact on the development of trade and crafts in the region. Almost all cities of Kyrgyzstan including the Osh city population are multi-ethnic. Population migration differs in different areas of southern Kyrgyzstan: $30.2 \%$ of respondents residing in the agricultural Bolshevik 
Table 3. External migration of the population by regions, in 2017 (Chynykeeva, 2019).

\begin{tabular}{cccc}
\hline Regions & $\begin{array}{c}\text { Arrived } \\
\text { (people) }\end{array}$ & $\begin{array}{c}\text { Departed } \\
\text { (people) }\end{array}$ & $\begin{array}{c}\text { Migration growth, } \\
\text { outflow (-) }\end{array}$ \\
\hline Kyrgyz Republic & 1974 & 5899 & -3925 \\
Batken & 168 & 236 & -68 \\
Zhalal -Abad & 215 & 535 & -320 \\
Issuk-kul & 75 & 291 & -216 \\
Naryn & 18 & 51 & -33 \\
Osh region & 141 & 567 & -426 \\
Talas & 105 & 242 & -137 \\
Chuy region & 468 & 1613 & -1145 \\
Bishkek & 633 & 2040 & -407 \\
Osh & 151 & 324 & -173 \\
\hline
\end{tabular}

area of the Kara-Suu district in the Osh region want to go to another place. $60.5 \%$ of respondents from this village do not want to leave their native places. Almost a tenth of the respondents have not yet decided on their departure.

As can be seen from Figure 2, young people mainly want to leave to work in another region of the republic and abroad. A more active position for leaving observed among young people aged from 21 - 25 years (47.2\%) and 16 - 20 years (47\%). People aged from 30 - 39 years have a higher percentage of respondents "I don't know", i.e. have not yet decided to leave, but have already taken a wait and see attitude. They said, if there would be at least some opportunity to leave, they would leave. As it turned out during our research, the older the age, the more people who do not want to leave.

\subsubsection{External Migration by Sub Regions}

The cause of migration in agricultural areas differs from foothill and mountainous areas. Here is a chart with data from various rural settlements representing sub regions of southern Kyrgyzstan.

Figure 3 is showing migration of population by sub-regions where unemployment is generally high in all areas with a significant number of residents. The Bolsheviks noted interethnic relations as the reason for migration, although there are very few representatives of other nationalities in the village. Respondents referred to interethnic relations with other ethnic groups in the city of Kara-Suu. The main reason for migration from agricultural areas was the lack of employment, dissatisfaction with the financial situation, lack of land, and other economic reasons. Migrants from agricultural areas are in a better position compared to the population of other sub-regions. The proximity of a large city and a city of regional significance provides many opportunities to satisfy the material and spiritual needs of potential migrants. It should be noted that the level of education of migrants from agricultural subregions is higher than that of other subregions. Migrants invest their earned money in the construction of a 


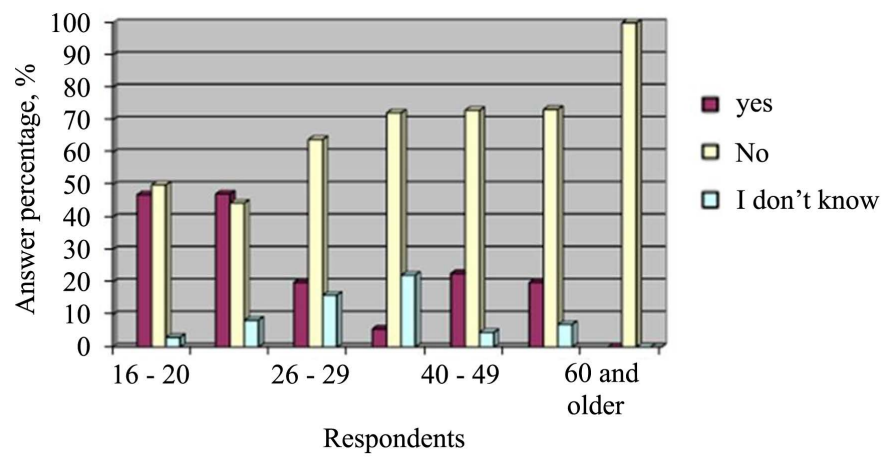

Figure 2. Respondents answer the question "Do you want to go to another place?" by age (in\%) (Chynykeeva, 2019).

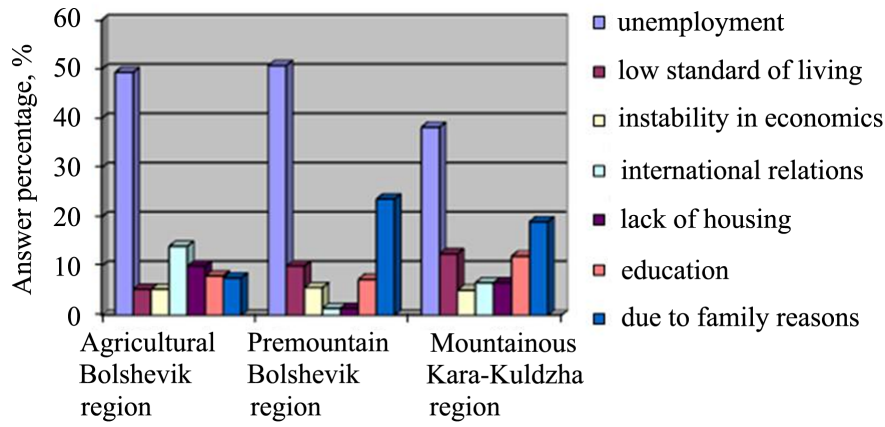

Figure 3. Migration by sub-regions (Chynykeeva, 2019).

new house, the purchase of a car, the education of children, and other significant family expenses.

Analysis of studied materials revealed objective regional causes of migration in the southern regions, characterized by difficult financial situation and low quality of life. This is associated with traditionally large families and low income per household member. For residents of southern Kyrgyzstan, labor migration is the most urgent need to get out of poverty and improve socio-economic status. In rural areas of the northern regions, members of relatively successful household owners land and income-generating assets from work in Russia.

For migrants of the northern regions, labor migration, as a whole, is a means of significantly improving their material situation, their implementation in the profession, and their career. As a result of discussions with family members of migrants, the main causes of migration were supplemented by other reasons: reluctance to engage in agriculture; the inability to repay loans and debts, the lack of funds, desire to buy a car, build a house, and start a business.

\subsection{Social Problem Survey}

The reasons for the migration of the Kyrgyz population in Batken, Jalal-Abad and Osh oblasts are, first of all, socio-economic, and then other reasons. The migration behavior of residents in the southern regions of Kyrgyzstan is associated with temporary travel of population outside the country. It identifies groups of people with active adaptive behavior, using both legitimate and illegi- 
timate methods of adapting to new living conditions, avoiding impoverishment, compensating for a sharp drop in incomes, gaining life experience in a market economy, mastering new professions, and raising skills.

However, this adaptive strategy carries not only a positive charge but also the threat of disintegration at the poles of the disposal of ethnic communities and families, turning parts of those who remain there into a kind of rentier, existing mainly in migrant transfers. To this are added the negative consequences of the return of migrants home, who bring into their native environment patterns of a foreign culture, stereotypes and norms of behavior borrowed in the host country, which can lead to phenomena such as the spread of deviant forms of behavior, social and cultural marginalization, and psychological disorientation of some migrants, and ultimately, all this threatens ethnocultural identity. The growth in the number of people who left the territory of the region cannot be attribute only to the mass departure of Russian-speaking peoples. In general, mass resettlement is characteristic of the Kyrgyz and Uzbeks and is associated with a change in the political situation for these peoples.

Recently departure of the population in the southern regions, as well as in the entire republic, to Russia and other countries has been intensifying. This is an objective process of the development of migration in the conditions of economic difficulties of the crisis and socio-political instability.

To the question, "What social problems, in your opinion, have worsened in Kyrgyzstan?" respondents answered that the most acute problem in Kyrgyzstan at present is unemployment. Every second respondent noted this problem as the most aggravated at present. All other social problems flow from here. The low level of wages, pensions, and benefits indicated $10 \%$ of respondents. Difficult economic situation, unemployment, and low wages force $8 \%$ of respondents to decide on external labor migration. The share of people in the respondents who noted the aggravation of the criminal situation and corruption in society is $7.6 \%$. Almost the same number of respondents noted the difficult economic situation in the country as an acute problem. Many unresolved social issues and a low standard of living, lack of work lead to the passivity of the population, demoralization of society. People cannot provide for their families, find their niche in society. Some cannot maintain their status and position. From a hard life, people begin to abuse alcohol. Lack of funds, poor living conditions, and disorganized leisure lead many young and not so young people to drugs. As a social problem, alcoholism and drug addiction are especially dangerous for the younger generation. The problem of alcoholism and drug addiction indicated by $4 \%$ of respondents. 2.2\% of respondents complain of aggravation of environmental problems. Table 4 is showing the number of respondents answered the question "What social problems have worsened at present?" by sex (Chynykeeva, 2019).

Analysis of a survey of men and women in Table 4 showed various answers. The aggravation of environmental situations was prevailed more in women (67.7\%) than in men (32.3\%). Women are not indifferent to the problems of interethnic relations (66.7\%). Difficulties in obtaining education for children, high 
Table 4. Respondents' answered the question "What social problems have worsened at present?" by sex (Chynykeeva, 2019).

\begin{tabular}{cccc}
\hline Respondents & Males & Females & Total \\
\hline Increase of unemployment & 45.2 & 54.8 & 49.8 \\
Low salary, pension, and benefits & 38 & 62 & 17 \\
Difficult economic situation & 50 & 50 & 6.1 \\
Alcoholism, drug addiction & 40.3 & 59.7 & 4 \\
Crime, corruption & 47.6 & 52.4 & 7.3 \\
Interethnic relations problems & 33.3 & 66.7 & 0.6 \\
Educational difficulties & 35.2 & 6.8 & 4 \\
External migration increased & 43.4 & 56.6 & 7.6 \\
Environmental problems & 32.3 & 67.7 & 2.2 \\
\hline
\end{tabular}

contracts for their education noted by $64.8 \%$ of women, and $35.2 \%$ of men. In many families where a woman is a livelihood provider, tuition fees and student support are borne by the mother. Therefore, among those who indicated this answer, there are more women.

In the traditional southern family, in most cases, they rely on sons and try to raise them first. Girls considered as future members of another family, so they remain in the background. Many girls receive secondary specialized education. In such educational institutions, the contract fee is lower and the duration of education is shorter, which allows you to get married earlier. In the south, recently the age of marriage is getting younger. Therefore, parents are interested in the girls earlier graduating from an educational institution and receive an appropriate document. $38 \%$ of men and $62 \%$ of women indicated low wages, pensions, and benefits. In our country, wages for women are lower than for men. This stated by many NGOs that deal with gender issues. Many women housewife, engaged taking care of children, household, and when the time comes for retirement, women receive an old-age pension without the length of service, and naturally, their pensions are small. Making child allowances requires collecting many certificates and papers to prove family income below the subsistence level. In other cases, the ratio of the number of men and women is not particularly different. An analysis of the materials showed that for young and older people, the main social problems are unemployment, low wages, pensions, and benefits, increased external labor migration of young people to other countries, the development of crime and corruption. Their positions on the choice of these four social problems are the same. For young people, another challenge is education. This indicated by $15 \%$ of the surveyed young people aged $16-30$ years. People of the older generation are worried about the increase in cases associated with alcoholism and drug addiction among young people. So, among 50 - 59-year old, $9 \%$ of respondents indicated this problem.

The level of education affects the indication of sore social problems of modern 
Kyrgyzstan. According to two answers, "unemployment increased", "low wages and pensions", the positions of people with different levels of education are similar. An increase in youth migration was noted by $8 \%$ of respondents with higher, secondary specialized, and secondary education. This problem was also indicated by more people with incomplete secondary education among other age groups (15\%) because among them there are more potential migrants. $6 \%$ of people with incomplete higher education indicated difficulties in obtaining an education. These people who are due to financial and other problems that could not graduate from universities and receive a diploma of higher education. Many of them temporarily interrupted their education and already working. Alcoholism and drug addiction as a social problem is more chosen among people with secondary education. $8.2 \%$ of people with secondary education complain about the difficult economic situation. The aggravation of crime, the prosperity of corruption worries almost a tenth of those surveyed with higher, incomplete higher, secondary specialized, and secondary education. Difficult interethnic relations and a worsening environmental situation were indicated by a very small number of respondents.

Analysis of the respondents' answers about professional conditions showed that unemployment, low wages, pensions, and benefits called the main social problems. Among the unemployed, transport workers, and farmers, more people noted an acute social problem as the outflow of the population to other countries (10\%). An increase in alcoholism and drug addiction indicated by $10 \%$ of management employees and $7 \%$ of trade workers.

For comparison of results obtained in this study, the ethnic and demographic features of the Mongols in China represented below which shows that Mongols of China are one of the largest non-Han peoples. According to the last census of 2010, there are 5,981,840 people. The 2000 census recorded 5,813,947 people. Thus, over the ten years, the growth amounted to more than 160 thousand. For China, this indicates slow growth. In 1964-1990, the number grew faster because the non-Han population (including the Chinese Mongols) was not involved in the state policy of birth control. Non-interference in demographic processes was due to a small number of peoples inhabiting the national outskirts and the urgent need to reproduce their labor resources. However, with the beginning of economic reforms, birth control measures began to spread to the non-Han population (Stavrov, 2013) which decreased the growth of the Mongolian population of China in the 1990s and 2000-2010s.

To combat corruption, it is necessary to restore order in the middle echelon of officials through tightening control over their activities, put an end to departmental rulemaking, and eliminate unnecessarily, often duplicate, administrative rules and procedures. Besides, it is necessary to minimize the contacts of civil servants with citizens and organizations, without fail to separate public services that establish rules for business from inspection bodies. To combat corruption, it is necessary to prohibit the formation of special funds and off-budget development funds by regulating entrepreneurial activity. Clearly define what types of 
gifts and services related to bribes or requisitions, achieve a comprehensive reform of the judicial system, and consolidate the existence of independent media at the legislative level.

\section{Conclusion}

After analyzing the respondent answers concerning various social and economic problems, the following conclusions were made. During the sovereignty of the republic, natural population growth was noticeable, which led to a certain demographic growth in the regions. Among many factors considered by us, which affect the ethnic-demographic process in the region, the main one was determined socio-economic. The ethnic composition of mountain pastoral zones in the south of Kyrgyzstan is becoming mono-ethnic. In the foothills and plains adapted for agriculture and cattle breeding, the multiethnic composition of the population is preserved. According to studies, due to the migration of Slavic ethnic groups to their historical homeland, the number of Kyrgyz, Uzbeks, and Tajiks among the people of the region increased their percentage in cities and regional centers increased. In the years of sovereignty, the population of the regions to improve the socio-economic situation migrated to neighboring and distant countries in search of new jobs and new sources of income. Resettlement, moving from one place to another, large-scale population resettlement cannot but change to some extent the socio-ethnic structure of a village or city in a new host area. The migration of the population of the region makes certain changes in the ethnic-demographic situation. The number of large families decreased; the percentage of distant families increased.

\section{Conflicts of Interest}

The authors declare no conflicts of interest regarding the publication of this paper.

\section{References}

Abdykalykov, O., Baizhumanov, D., Osmonaliev A., Tulegabylov, N., Kim, A., Koichumanova, K., Plesovskikh, R., \& Turdubaeva, C. (2010). Census of the Population and Housing Stock of the Kyrgyz Republic in 2009. Book III (in Tables). Bishkek: Regions of Kyrgyzstan.

Asankanov, A. A. (2009). Ethnodemographic and Migration Processes in the South of Kyrgyzstan (Research Project). Materials of Ethnosociological Research of 2009 on the Scientific Project.

Bromley, Yu. V. (1987). Ethnosocial Processes: Theory, History, Modernity (334 p.). Moscow: Nauka.

Brook, S. I. (1986). World Population Ethno-Demographic Reference Book (828 p.). Moscow: Nauka.

Brooke, S. I., \& Kabuzan, V. M. (1991). Migration Processes in Russia and in the USSR. Moscow: NION RAS.

Chynykeeva, G. E. (2019). Migration and Ethno-Demographic Processes in Osh, Batken 
and Jalal-Abad Oblasts. Materials of Ethnosociological Research of 2019 for the Scientific Project.

Fei, X. (2017). The Formation and Development of the Chinese Nation with Multi-Ethnic groups. International Journal of Anthropology and Ethnology, 1, Article No. 1. https://doi.org/10.1186/s41257-017-0001-z

Gabbert, W. (2006). Concepts of Ethnicity. Latin American and Caribbean Ethnic Studies, 1, 85-103. https://doi.org/10.1080/17486830500510034

Han, E., \& Paik, C. (2017). Ethnic Integration and Development in China. World Development, 93, 31-42. https://doi.org/10.1016/j.worlddev.2016.12.010

Ismayilova, L., Lee, H. N., Shaw, S., El-Bassel, N., Gilbert, L., Terlikbayeva, A., \& Rozental, Y. (2014). Mental Health and Migration: Depression, Alcohol Abuse, and Access to Health Care among Migrants in Central Asia. Journal of Immigrant and Minority Health, 16, 1138-1148. https://doi.org/10.1007/s10903-013-9942-1

Kozlov, V. I. (1969). Dynamics of the Number of Peoples (240 p.). Moscow: Nauka.

Lee, R. (2011). The Outlook for Population Growth. Science, 333, 569-573. https://doi.org/10.1126/science.1208859

Nedoluzhko, L., \& Agadjanian, V. (2015). Between Tradition and Modernity: Marriage Dynamics in Kyrgyzstan. Demography, 52, 861-882.

https://doi.org/10.1007/s13524-015-0393-2

Rusi, J., \& Cinnirella, M. (2012). The Construction of Ethnic Identity: Insights from Identity Process Theory. Ethnicities, 12, 503-530. https://doi.org/10.1177/1468796811432689

Stavrov, V. (2013). Tendencies of Demographic Development of Non-Han Nationalities of Northeastern China (Beginning of the 21st Century). Herald of the Far Eastern Branch of the Russian Academy of Sciences, 4, 146-151.

Sulaimanov, E. Zh. (1995). Southern Kyrgyzstan: Current and Ethno-Demographic Situation. Zaman Kyrgyzstan.

Sultanov, A., Chuikov, N., Orosbaev, A., Isaliev, K., Shakulov, A., Turdubaeva, Ch., Biryukova, V., \& Isenkulova, E. (2018). Demographic Yearbook of the Kyrgyz Republic. Bishkek.

Tzaneva, E. (2019). Ethno-Cultural Symbolism and Group Identity. In S. Ratuva (Ed.), The Palgrave Handbook of Ethnicity (pp. 1-20). Singapore: Palgrave Macmillan. https://doi.org/10.1007/978-981-13-0242-8 2-2

Williams, R. (1994). The Sociology of Ethnic Conflicts: Comparative International Perspectives. Annual Review of Sociology, 20, 49-79. http://www.jstor.org/stable/2083359 https://doi.org/10.1146/annurev.so.20.080194.000405

Yang, S. (2017). A Review of Chinese Ethnology in the Past Hundred Years and Its Summary in the New Era. International Journal of Anthropology and Ethnology, 1, Article No. 6. https://doi.org/10.1186/s41257-017-0002-y 